\title{
CONSUMER REACTIONS TO UNOBSERVED CHANGES IN PRICE SCHEDULES
}

\author{
Peter Katuščák
}
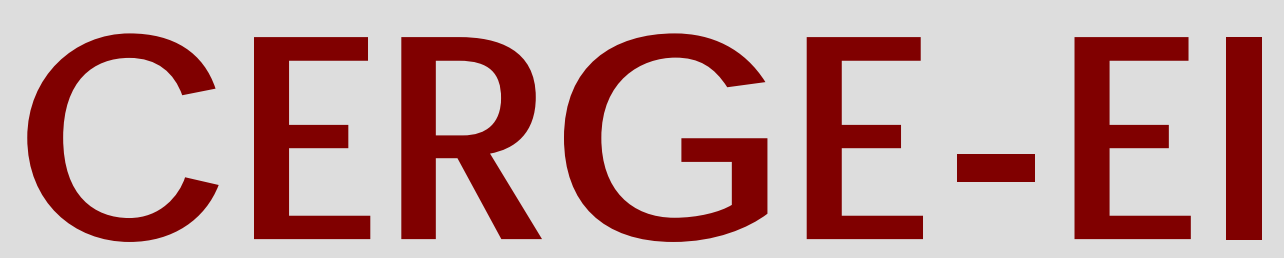

Charles University Centerfor Economic Research and Graduate Education Academy of Sciences of the Czech Republic Ec onomic s Institute 


\title{
Working Paper Series 433 (ISSN 1211-3298)
}

\section{Consumer Reactions To Unobserved Changes in Price Schedules}

\author{
Peter Katuščák
}

CERGE-EI

Prague, February 2011 
ISBN 978-80-7343-234-8 (Univerzita Karlova. Centrum pro ekonomický výzkum a doktorské studium)

ISBN 978-80-7344-224-8 (Národohospodářský ústav AV ČR, v.v.i.) 


\title{
Consumer Reactions To Unobserved Changes in Price
}

\author{
Schedules *
}

Peter Katuščák ${ }^{\dagger}$

December 30, 2010

\begin{abstract}
Economic theory presumes that individuals respond to true marginal prices when deciding on the amount of goods and services they buy and many other economic decisions. However, learning about these marginal prices is often costly in terms of search time, cognitive effort or monetary outlays. This is likely to be true of price changes in subscription plans. Consumers may therefore opt to be satisfied with only an approximate knowledge of the relevant marginal prices. This paper presents an experiment that studies repeated consumer purchase and price information updating and acquisition decisions when parameters of the price schedule are serially correlated but unknown. Subjects have an option to acquire the pricing information at a cost, or otherwise just update their beliefs based on the observation of the total cost of purchase. We find the following: (1) conditional on information acquisition decisions, the model of Bayesian updating provides a good approximation for revealed mean beliefs about the per-unit price held by subjects who appear to understand the experiment and/or report their expected cost of purchase accurately; it is not a good approximation for other subjects; (2) the demand for information decreases with the cost of information, as expected; (3) controlling for Bayesian beliefs and cost of information, the demand for information does not vary with the length of the remaining time horizon in which the information can be used, contrary to the theoretical prediction; (4) large positive surprises in the cost of purchase in the most recent period increase information demand, whereas negative surprises decrease it, relative to the no-surprise baseline, which is contrary to the theoretical prediction.
\end{abstract}

Keywords: price scheme, complexity, consumer decisions JEL Classification: D12, D83

*I would like to thank Marek Rusnák for excellent research assistance. Financial support from the Grant Agency of the Czech Republic (402/09/2048) is gratefully acknowledged. Any remaining errors are mine.

${ }^{\dagger}$ CERGE-EI, P.O.Box 882, Politických vězňů 7, 11121 Praha 1, Czech Republic, Peter.Katuscak@cergeei.cz. 


\begin{abstract}
Abstrakt
Ekonomická teorie předpokládá, že jedinci reagují na skutečné marginální ceny při rozhodování o množství zboží a služeb, které nakupují, a při mnoha dalších ekonomických rozhodnutích. Nicméně, zjištování těchto marginálních cen je často nákladné z hlediska času, kognitivního úsilí anebo penežních výdajů. Týká se to např́íklad změn v cenách paušálních spotřebitelských plánů a doplňkových služeb. Spotřebitelé se můžou v takové situaci rozhodnout, že budou spokojeni s pouze přibližnou znalostí př́slušních marginálních cen. Tento článek představuje experiment, který studuje opakované spotřebitelské nákupy a rozhodnutí o aktualizaci a získávání cenových informací v prostředí, kde jsou cenové parametry sériově korelovány, ale neznámé. Subjekty mají možnost získat informace o těhto parametrech za určitou cenu, nebo jen aktualizovat své přesvědčení na základě pozorování celkových nákladů nákupu. Zjištujeme, že: (1) podmíněně na rozhodnutích o získávání informací, model Bayesiánské aktualizace poskytuje dobrou aproximaci pro odhalené průměrné přesvědčení o jednotkové ceně u subjektů, které se zdají, že chápou experiment anebo reportují své očekávané náklady na nákup přesně, zatím co tato aproximace není dobrá pro jiné subjekty; (2) poptávka po informacích se snižuje s náklady na informace, jak se očekávalo; (3) kontrolujíc pro Bayesiánské přesvědčení a náklady na informace, poptávka po informacích se nemění s délkou zbývajícího časového horizontu, ve kterém můžou být tyto informace použity, v rozporu s teoretickou předpovědí; (4) velké pozitivní překvapení v celkové ceně nákupu v předcházejícím období vedou ke zvýšení poptávky po cenových informacích, zatímco negativní překvapení ji snižují, v porovnání s efektem malých překvapení, co je v rozporu s teoretickou předpovědí.
\end{abstract}




\section{Introduction}

Economic theory presumes that individuals respond to true marginal prices when deciding on the amount of goods and services they buy, their labor supply, portfolio allocation, saving and borrowing decisions, usage of cell phone minutes, and many other behavioral margins. It is questionable, however, whether individuals are aware of true marginal prices when they face a complex and changing pricing scheme. As an illustration, consider the following examples:

(a) Mobile phone subscription plans: A typical mobile phone subscription plan stipulates a fixed charge for a package of included services, and a set of per-unit prices to be charged for individual services once the included allotment is exhausted. Individual services most typically include calling minutes and SMS and MMS messages that are distinguished by the destination network and/or source and destination countries, time of day, weekdays vs. weekends, holidays, etc. These per-unit prices often differ greatly depending on the combination of underlying characteristics of the product. In addition, true marginal prices are also affected by consumption taxes that may be more or less salient.

(b) Energy billing: Utility bills usually break down charges into meter fees, production charges, transmission charges, excise-tax-type charges and consumption charges. There may also be unit-price differentials depending on the time of day when the consumption takes place. It is often less than straightforward to figure out from this bewildering array of numbers what the true marginal price of an additional kilowatt-hour of electricity consumption is.

(c) Income and payroll taxes: How much, taking into account income and payroll taxtransfer systems at all levels of government, is an employee going to net out from an additional hour of labor? The answer to this question depends on the level of income of the worker and its sources, marital status and spouse's income, number and age of children, income and payroll tax systems at all levels of government and their interaction, and also the additional benefits, if any, that such payroll taxes may bring in the future in terms of government-provided old-age pension benefits. Taking into account all of these effects, 
a worker may often have only an approximate idea about the effective marginal tax rate applied to his wage.

(d) Usage of credit and credit cards: Consumers are regularly barraged by advertisements offering them credit of all sorts. The costs of taking up such credit are often made non-transparent, whereas the benefits of immediate gratitude are made salient. What is the true implicit interest rate that a debtor will end up paying at the end of the day?

Searching through details of such pricing schemes is often costly in terms of time, cognitive effort and sometimes even money (hiring a tax advisor, for example). Consumers may therefore often opt to acquire less that a perfect knowledge of the pricing scheme in question. To add to the complexity, such price schemes often change with time (witness changes in income tax systems or mobile phone plans). How is a consumer going to change the amount of underlying consumption or labor supply in response to such changes? If it is costly to understand true marginal prices the first time around, going through this process after price scheme changes may be even less appealing, unless there is a reason to believe that the change is large enough to warrant incurring such information costs.

This paper presents a laboratory experiment that aims to add to our understanding of consumers' behavior when faced with such price schemes. In particular, the subjects are faced with a time series of two-part tariffs, and they are asked to choose the number of units of a fictitious good to buy in every period. The fixed fee is independently and identically distributed in each period, whereas the per-unit price is serially correlated. Subjects are not told in any of the periods what the parameters of the pricing scheme are, but they have an option to acquire such information at a cost before making their purchase decision. After deciding on the number of units they want to buy, they also provide an estimate of the total cost of their purchase and then they are informed of their actual payment in that period. This information is a noisy signal of the per-unit price in the given period, and subjects may choose to rely on this signal in the following period(s) rather than to buy costly information.

This design aims to capture some of the essential choices experienced by consumers that have to decide on the quantity of consumption when facing a complex and changing 
pricing scheme. In particular, the paper aims to shed light on two questions: (1) When do consumers decide to pay the cost to acquire pricing information? (2) If they decide not to do so, how do they update their beliefs about the per-unit price from their observation of their total purchase bills?

There are four main results: (1) conditional on information acquisition decisions, the model of Bayesian updating provides a good approximation for revealed mean beliefs about the per-unit price held by subjects who appear to understand the experiment and/or report their expected cost of purchase accurately; it is not a good approximation for other subjects; (2) the demand for information decreases in the cost of information, as expected; controlling for Bayesian beliefs and cost of information, the demand for information does not vary with the length of the remaining time horizon in which the information can be used, contrary to the theoretical prediction; (4) large positive surprises in the cost of purchase in the most recent period increase information demand, whereas negative surprises decrease it, relative to the no-surprise baseline, which is contrary to the theoretical prediction.

The rest of the paper is structured as follows. Section 2 surveys the relevant literature. Section 3 describes details of the experimental design. Section 4 outlines various hypotheses to be tested based on the experimental design. Section 5 discusses the empirical findings. Finally, Section 6 concludes.

\section{Literature Review}

Shin (1985) documents that consumer demand for electricity is more responsive to the average price realized in the previous billing cycle than to the actual marginal price. de Bartolome (1995) experimentally documents that when a tax schedule is presented in the form of a table, a non-negligible fraction of subjects (incorrectly) react to the average tax rate. On the other hand, if the marginal tax rate is stressed, they (correctly) react to the marginal tax rate. Gaudin (2006) finds that based on differences in the design of water bills in various parts of the U.S., consumers have a more price-elastic demand when price information is explicitly displayed on the bill. 
Liebman and Zeckhauser (2004) generalize these observations and suggest that when individuals have a limited understanding of the actual price schedule they face, they default to "schmeduling," a rule of thumb which approximates the unknown true marginal price. In the first form of schmeduling, labeled "ironing," the approximation is given by the average price realized in the previous period. In the second form of schmeduling, labeled "spotlighting," a global approximation is given by the marginal price faced at the current level of consumption, ignoring any nonlinearities in the schedule.

Feldman and Katuščák (2010) develop a formal model of understanding complex pricing schedules that generalizes the standard decision-maker (DM) model by allowing pricing schedule misperception. A DM is subject to a linear pricing schedule that changes from period to period due to innovations that are predictable well in advance, as well as innovations that are predictable only a short time in advance. The DM perceives these innovations with noise and is uncertain about the exact current pricing scheme. The DM will use any signal generated during his interaction with the pricing system to update his beliefs. The authors also present empirical evidence on the impact of lump-sum tax changes on labor income that is consistent with such behavior.

\section{Experimental Design}

The experimental design attempts to approximate field situations such as the ones described in the examples given in the Introduction. When facing recurring billing, the final bill is affected both by demand and pricing schedule variation over time. This study focuses on the latter element. Presence of a stochastic demand (and imperfect recall of its realization) adds another layer of noise into the signal extraction problem about prices, and it is excluded from this study. Its role is partly assumed by a fixed fee (described below) that varies from one period to another.

An important assumption in the design is the presence of positive costs of acquiring pricing information. This reflects an empirical observation that although precise pricing information can almost always be pieced together, such process does take time, cognitive 
resources and sometimes even a financial outlay. Although companies often notify their customers of price changes, this may frequently involve just a reference to a website or printed material (many income tax systems being prime examples). As a result, costs of gathering information are not entirely eliminated by such announcements. Moreover, it may not be clear upfront how much time, effort and perhaps money will be necessary to obtain the relevant pricing information. Is it readily available with just a few mouse clicks? Or is it necessary to browse through multiple websites and online documents to piece it together? How many? How long will it take? If some information is only available in offline form (elements of the tax system, for example), how much time, effort and money will it take to obtain it? How long will it take to figure out how to piece together partial information (such as charges for electricity generation, transmission, distribution, meter fees, etc.)? What if some information is conflicting? Apart from the fixed and known cost of information, the design will therefore also account for the case when this cost is random with a known distribution and the case when it is ambiguous, with only possible realizations being known.

Subjects for this experiment were recruited using the Online Recruitment System for Economic Experiments (ORSEE). Upon arriving to the lab, each subject drew a number of a computer terminal and was then seated at that terminal for the duration of the experiment. The experiment was conducted in English ${ }^{1}$ using the $\mathrm{z}$-Tree software (Fischbacher, 2007). Each subject received a printed copy of the instructions (included in Appendix C). Each experiment started by an experimenter reading the instructions outloud. The body of the experiment consisted of one practice stage of five periods and six payoff stages, each of 12 periods. At the end of the experiment, a questionnaire collecting demographic information, some information about subjects' mobile phone plan, usage, and price knowledge and tax rate knowledge was administered.

\footnotetext{
${ }^{1}$ Running experiments in English is a common practice in Prague. The invitation email was sent in English and it explicitly stated that the experiment would be conducted in English and that only persons with a sufficiently good command of English should register for sessions.
} 


\subsection{Purchasing Decisions}

In each round, a subject is asked to decide on the number of units $x \in\{1,2, \ldots, 10\}$ of a fictitious good to buy. The experiment employs an induced demand schedule given by the marginal valuation, in terms of experimental currency units (ECUs), given by

$$
v(x) \equiv 11.5-x+20 I_{\{x=1\}},
$$

where $I_{\{\cdot\}}$ is an indicator function. The cumulative valuation schedule in terms of ECUs is accordingly given by

$$
V(x) \equiv 20+11 x-\frac{x^{2}}{2} .
$$

Table 1 displays marginal and total valuations for all possible values of $x$. An analogous table is displayed in the instructions (see Appendix C). Note that a subject must always buy at least one unit.

The good is priced in terms of ECUs using a two-part tariff

$$
C(x)=F+p x
$$

where $F$ is the fixed fee and $p$ is the per-unit price. That is, net of possible information costs (see below), the per-period payoff when the subject purchases $x$ units is given by $V(x)-C(x)$. The fixed fee $F$ is drawn randomly by the computer in every period from the set $\{0,1,2, \ldots, 20\}$, with each of the 21 values having an equal probability, $1 / 21$, of being selected. This fee is determined independently in every period and fees in different periods are not related. The per-unit price in any period takes one of the values from the set $\{1,2, \ldots, 10\}$. In the first period of every stage, the computer draws the per-unit price randomly from the set $\{1,2, \ldots, 10\}$, with each of the 10 values having an equal probability, $1 / 10$, of being selected. In every subsequent period of that stage, the per-unit price for that period is determined as follows:

(a) With probability $1 / 2$, the per-unit price is equal to the per-unit price in the previous 
period.

(b) With probability $1 / 3$, the per-unit price changes by 1 compared to the per-unit price in the previous period. In this case, the per-unit price is equally likely to increase or decrease by 1 , unless the price in the previous period is 1 , in which case only an increase is possible, or 10, in which case only a decrease is possible.

(c) With probability $1 / 6$, the per-unit price changes by 2 compared to the per-unit price in the previous period. In this case, the per-unit price is equally likely to increase or decrease by 2 , unless the price in the previous period is 1 or 2 , in which case only an increase is possible, or 9 or 10, in which case only a decrease is possible.

Analytically, this per-unit price transition process can be captured by the Markovian transition matrix $A$ displayed in Table 2.

Subjects are not automatically informed about $F$ and $p$ in any given period. However, at the beginning of each period, before making their purchase decisions, subjects have an option to acquire information about the exact values of $F$ and $p$ in that period at a cost $c \in\{2,4,6,8\}$. Subjects are also initially told that the realization of $c$ may change from period to period within a given stage and that they may or may not be given additional details about the realizations of $c$ in a given stage before they decide whether to acquire the information. In the practice stage, $c$ is drawn randomly and independently from the set $\{2,4,6,8\}$ in each period, with each of the 4 values having an equal probability, $1 / 4$, of being selected. Realizations are disclosed to subjects before they decide whether to acquire the information or not. In four out of six payoff stages, the cost is known and constant throughout the stage. These four stages span all four values in the set. In what follows, they will be referred to as $S 2, S 4, S 6$ and $S 8$, where the digit denotes the value of $c$ in that stage. In the remaining two stages, $c$ is drawn randomly and independently from the set $\{2,4,6,8\}$ in each period, with each of the 4 values having equal probability, $1 / 4$, of being selected. However, unlike in the practice stage, the cost realizations are not disclosed to the subjects before they decide whether to acquire the information or not. In one of the two stages, called the "risky stage" and denoted by $S R$, the subjects are told that all four 
potential realizations of $c$ are equally likely. In the other one, called the "ambiguous stage" and denoted by $S A$, the subjects are only told about the four potential realizations of $c$, but they are not given any information about the probabilities of the individual values to be drawn. In half of the sessions, the first four stages are a permutation of $S 2, S 4, S 6$ and $S 8$ randomized across subjects, and they are followed by $S A$ and $S R$, respectively. The other half of the sessions start with $S A$ and $S R$, respectively, followed by a permutation of $S 2, S 4, S 6$ and $S 8$ which is randomized across subjects. This is done in order to minimize the impact of any potential order effects on aggregate results. The reason for $S A$ preceding $S R$ in all sessions is that the opposite ordering might have a strong anchoring effect on beliefs about the distribution of $c$ in $S A$.

In any given period, the sequencing of events is as follows:

1. In stages $S 2, S 4, S 6$ and $S 8$, the subjects are informed about the cost of information. In stage $S R$, they are informed about the distribution of this cost. In stage $S A$, they are informed about potential realizations of this cost. Then the subjects are asked whether they want to acquire the pricing information or not. In the former case, the values of $F$ and $p$ are revealed to the subjects.

2. The subjects are asked decide on the quantity $x \in\{1,2, \ldots, 10\}$ of the fictitious good to buy.

3. The subjects are asked to give their estimate $C^{e}$ of the amount $F+p x$ they are going to pay for their purchase.

4. The subjects are given a feedback after each period that contains their decision whether to acquire the pricing information or not, the realized cost $c$ of the acquired information in the former case, the purchased quantity $x$ of the good, its cumulative valuation $V(x)$, its true cost $C(x)$, the subject cost estimate $\widetilde{C}(x)$, and the overall period payoff of $V(x)-C(x)-c$ if the pricing information is acquired and $V(x)-C(x)$ otherwise.

Denoting the average ECU earnings across the 72 payoff periods by $\pi$, cash earnings 
from the experiment in terms of Czech crowns (CZKs) are given by $\min \{m(\pi-15), 0\}+S$, where $m$ is a multiplier and $S$ is a show-up fee. The default values of $m$ and $S$ are 20 and CZK 100, respectively. Subjects are informed of these parameter values at the beginning of the experiment.

Eight sessions were run in total during two days in December 2009. All of them were implemented in the CERGE-EI experimental laboratory in Prague. In sessions 1-4, $S A$ and $S R$ came at the end, whereas in sessions 5-8, they came at the beginning. In sessions 2 and 4, the payoff multiplier $m$ was ex post increased from 20 to 24 and 28 , respectively, and in session 5, the show-up fee $S$ was ex post increased from CZK 100 to CZK 140. These ex post changes were done in order to bring the average session payoff close to the promised average payoff in the experiment. Altogether, 107 subjects, mostly university students from various schools in Prague, participated in the experiment. Individual sessions took between 90 and 120 minutes and the average payoff was CZK 341, which was approximately EUR 13 according to the exchange rate at the time (EUR $1=$ CZK 26.3).

\subsection{Questionnaire}

The questionnaire (included in Appendix D) was administered at the end of each experimental session. ${ }^{2}$ We collected the following demographic information: gender, age, country of origin, number of siblings, academic major and the highest earned degree up until the date of the experiment. We then asked about mobile phone usage (provider, plan name, frequency of exceeding the plan limits) and knowledge of over-the-limit per-minute pricing (day during weekdays, evening during weekdays, weekends and holidays). Next, we asked about knowledge of the income tax rate on regular labor contracts, irregular labor contracts, and interest earnings and also about value added tax rates. Finally, we asked subjects to describe how they decide: (a) whether to buy pricing information; (b) how many units of the good to buy if they know the fixed fee and the per-unit price; (c) how to update their beliefs about the per-unit price from their observation of the actual cost of

\footnotetext{
${ }^{2}$ Subjects were not paid for filling out the questionnaire, but they had to fill out answers to mandatory questions in order to get to the end of the session on their screen.
} 
the purchase. Analysis of the questionnaire responses in subject to a separate companion paper.

\section{Hypotheses}

We are interested in addressing two questions in this study. First, how do subjects update their beliefs about relevant price parameters from observations of their total cost of purchase in the previous billing cycle(s)? Second, how do subjects decide on when to acquire pricing information? The following two subsections develop theoretical benchmarks based on rationality and risk neutrality and develop the resulting hypotheses.

\subsection{Updating of Beliefs}

We begin by considering the first question: how do subjects update their beliefs about relevant price parameters from observations of their total cost of purchase? Note that we do not directly observe subjects' beliefs about the fixed fee and the per-unit price in any of the periods. It is reasonable to assume that these beliefs are degenerate at the revealed values of the two pricing parameters in any period in which a subject acquires the pricing information. But what about periods in which a subject does not acquire this information? Assuming rationality and, in the second case, also risk neutrality, there are two ways to extract the subject's expectation of the per-unit price in a particular period from the information provided by the subject in that period. First, in each period $t$, the subject reports how much he or she expects to pay in total, i.e., his or her expectation of $F_{t}+p_{t} x_{t}$, for the quantity $x_{t}$ that he or she is purchasing. Denote this estimate by $C_{t}^{e}$. Recall that in each period $F_{t}$ is independently drawn from the uniform distribution on $\{0,1, \ldots, 20\}$, and hence, under rational expectations, $E\left(F_{t}\right)=10$. Since the subject controls $x_{t}$ directly, ignoring discrete grid issues, his or her implied expectation $p_{t}^{e}$ of $p_{t}$ is then given by

$$
p_{t}^{e}=\frac{C_{t}^{e}-10}{x_{t}}
$$


Second, we can extract the subject's expectation of $p_{t}$ from the observation of $x_{t}$ in a period in which he or she did not acquire the pricing information. To see the argument, consider the decision about the optimal quantity to demand in any such period. Inspecting the induced demand displayed in Table 1, the payoff of purchasing $x$ units of the good when the fixed fee is $F_{t}$ and the per-unit price is $p_{t}$ is

$$
20+(11.5-1)+\ldots+(11.5-x)-p_{t} x-F_{t}
$$

Since the subject does not know the realizations of $F_{t}$ and $p_{t}$, assuming rationality and risk neutrality, the subject will choose a value of $x_{t}$ that maximizes his or her expected payoff. Note that since $F_{t}$ is an additive term in the payoff function, its expectation plays no role in this choice. Hence with $p_{t}^{e e}$ being the subject's expected value of $p_{t}$, maximizing the expected payoff is equivalent to choosing $x_{t}$ such that

$$
\begin{aligned}
x_{t} & \in \underset{x \in\{1, \ldots, 10\}}{\arg \max }(11.5-1)+\ldots+(11.5-x)-p_{t}^{e e} x \\
& =\underset{x \in\{1, \ldots, 10\}}{\arg \max } \frac{1}{2}\left(11-p_{t}^{e e}\right)^{2}-\frac{1}{2}\left[x-\left(11-p_{t}^{e e}\right)\right]^{2} .
\end{aligned}
$$

As a result, given $p_{t}^{e e}$, it is optimal to purchase an integer quantity that is closest to $11-p_{t}^{e e}$. Ignoring the discrete grid issues, it is optimal to purchase

$$
x_{t}^{*}=11-p_{t}^{e e} \text {. }
$$

By reverse engineering, if the subject purchases $x_{t}$ units of the good, assuming that he or she behaves optimally, the implied value of $p_{t}^{e e}$ is given by

$$
p_{t}^{e e}=11-x_{t}
$$

The equations (4) and (8) then give two alternative estimates of the subject's expectation of $p_{t}$.

Next, we need to formulate a theoretical benchmark for the evolution of subjects' 
beliefs about the per-unit price throughout a stage (12 periods). This benchmark is going to be based on rationality, risk neutrality and Bayesian updating. Note that a subject has two sources of information about the per-unit price in a given period. First, he or she may acquire its exact value at a cost. In this case the belief about the per-unit price collapses to a degenerate distribution. Second, if the belief in non-degenerate to start with, the subject may update it in a Bayesian way based on the observation of his or her total cost of purchase in each period. Formally, denote by $a \equiv\left(a_{1}, \ldots, a_{12}\right) \in\{0,1\}^{12}$ the subject's time path of information acquisition in a given stage, where $a_{t}=1$ if the subject acquired pricing information in period $t$ and $a_{t}=0$ otherwise. Then let $\bar{p} \equiv\left(\bar{p}_{1}, \ldots, \bar{p}_{12}\right) \in$ $[\oslash \cup\{1, \ldots, 10\}]^{12}$ be the subject's time path of acquired information about the per-unit price, with $\bar{p}_{t}$ being defined only in periods in which $a_{t}=1$. Also let $x \equiv\left(x_{1}, \ldots, x_{12}\right) \in$ $\{1, \ldots, 10\}^{12}$ be the subject's time path of quantities demanded and let $C \equiv\left(C_{1}, \ldots, C_{12}\right) \in$ $\{1, \ldots, 120\}^{12}$ be the subject's time path of realized total cost of purchase amounts. Finally, let $\omega^{E A} \equiv\left(\omega_{1}^{E A}, \ldots, \omega_{12}^{E A}\right) \in S_{10}^{12}$, where $S_{10}$ is a 10 -dimensional unit simplex, and let $\omega^{E P} \equiv$ $\left(\omega_{1}^{E P}, \ldots, \omega_{12}^{E P}\right) \in S_{10}^{12}$ be the subject's time path of ex ante (before realizing the amount paid for the purchase but after observing pricing information, if acquired, in a period) and ex post (after realizing the amount paid for the purchase in a period) beliefs about the per-unit price $p_{t}$. Then the evolution of the subject's beliefs under Bayesian updating is given by the following Proposition (proof in Appendix B):

Proposition 1 Assuming Bayesian updating, the evolution of beliefs over the 12 periods of a stage is given by the following:

1. If $a_{t}=1$, then both $\omega_{t}^{E A}$ and $\omega_{t}^{E P}$ are degenerate at $\bar{p}_{t}$.

2. If $a_{t}=0$, then

$$
\omega_{t}^{E A}=\left\{\begin{array}{ll}
\frac{1}{10} r & \text { if } t=1 \\
A \omega_{t-1}^{E P} & \text { if } t \geq 2
\end{array},\right.
$$

where $r$ is a 10-dimensional column vector of 1 , and

$$
\omega_{t}^{E P}=\frac{\operatorname{diag}\left[v\left(C_{t}, x_{t}\right)\right] \omega_{t}^{E A}}{v\left(C_{t}, x_{t}\right)^{T} \omega_{t}^{E A}},
$$


where $v:\{1, \ldots, 120\} \times\{1, \ldots, 10\} \rightarrow\{0,1\}^{10}$ is a column indicator vector defined by

$$
v_{p}(C, x) \equiv I_{\left\{\frac{C-20}{x} \leq p \leq \frac{C}{x}\right\}}, p \in\{1, \ldots, 10\}
$$

This result can be used recursively to construct the entire vectors $\left(\omega_{1}^{E A}, \ldots, \omega_{12}^{E A}\right)$ and $\left(\omega_{1}^{E P}, \ldots, \omega_{12}^{E P}\right)$. Based on this, the theoretical benchmark for $p_{t}^{e}$ and $p_{t}^{e e}$ as computed in (4) and (8) is given by $u^{T} \omega_{t}^{E A}$, where

$$
u^{T} \equiv[1,2,3,4,5,6,7,8,9,10]
$$

Hence we can formulate hypotheses about belief updating behavior:

Hypothesis 1 The expected value of $p_{t}^{e}$ in the population of potential experimental subjects conditional on $u^{T} \omega_{t}^{E A}$ is given by $u^{T} \omega_{t}^{E A}$. That is,

$$
E\left(p_{t}^{e} \mid u^{T} \omega_{t}^{E A}\right)=u^{T} \omega_{t}^{E A}
$$

Hypothesis 2 The expected value of $p_{t}^{e e}$ in the population of potential experimental subjects conditional on $u^{T} \omega_{t}^{E A}$ is given by $u^{T} \omega_{t}^{E A}$. That is,

$$
E\left(p_{t}^{e e} \mid u^{T} \omega_{t}^{E A}\right)=u^{T} \omega_{t}^{E A}
$$

\subsection{Information Demand}

We now turn to the second question of this study: how do subjects decide on when to acquire the pricing information? Under rationality and risk neutrality, in any period $t$ within a stage, such a decision involves comparing the expected value of acquired information to its cost. Although one could in principle computationally solve the full dynamic decision tree to create a theoretical benchmark (like in the previous subsection), given the size and dimensionality of the belief, or, equivalently, state space $\left(S_{10}\right)$, this is computationally very demanding even for the coarsest choices of the grid for beliefs about the per-unit price. 
Instead, we focus on formulating three simple hypotheses based on the logic underlying the decision tree.

We begin with a few observations. Given a subject's belief about the per-unit price at the end of period $t-1$, the value of acquiring the pricing information in period $t$ increases with the number of the remaining periods, and hence decreases with $t$. This is because one can always discard the obtained information about the per-unit price after a certain number of periods, but it is in general not optimal to do so. Hence, given this belief and the (expected) cost of information, the demand for information decreases with $t$. Clearly, it is also the case that, given a subject's belief about the per-unit price at the end of period $t-1$ and given $t$, the demand for information decreases with the (expected) cost of information. Although $t$ and the (expected) cost of information are readily available, subjects' beliefs are not. We therefore impute them based on Proposition 1. This leads to the following pair of hypotheses:

Hypothesis 3 Controlling for $\omega_{t-1}^{E P}$ derived from Proposition 1 and the probability of acquiring the pricing information in period $t$ decreases with the (expected) cost of information.

Hypothesis 4 Controlling for $\omega_{t-1}^{E P}$ derived from Proposition 1 and the (expected) cost of information, the probability of acquiring the pricing information in period $t$ decreases with $t$.

The last hypothesis we are going to formulate is based on the observation that the per-unit price transition process is symmetric with respect to the level of the per-unit price in that the probability of a per-unit price path $\left(p_{1}, \ldots, p_{12}\right)$ is the same as that of $\left(11-p_{1}, \ldots, 11-p_{12}\right)$. As a result, if subjects do not on average deviate in their estimate, $C_{t}^{e}$, of the cost of purchase from the true realization, $C_{t}$, of this cost, then we would expect that positive and negative cost surprises, $C_{t}^{e}-C_{t}$, should on average have a symmetric impact on the probability of obtaining the pricing information in the next period. In fact, as discussed in the next section, in periods when $\left(F_{t}, p_{t}\right)$ is known, the average discrepancy 
between $C_{t}^{e}$ and $C_{t}$ is -0.23 , statistically insignificantly different from zero. This evidence therefore supports the presumption of the claim. These observations motivate the following hypothesis:

Hypothesis 5 Controlling for the cost of information and the probability of acquiring the pricing information reacts symmetrically to equally-sized, in absolute value, positive and negative realizations of $C_{t-1}^{e}-C_{t-1}$.

This concludes the development of the theoretical hypotheses. The next section presents empirical results that address the hypotheses developed in this section.

\section{Results}

This section presents empirical tests of the hypotheses outlined in the previous section. In subsection 5.1, we analyze hypotheses regarding updating of beliefs presented in subsection 4.1. In subsection 5.2, we analyze hypotheses regarding information demand presented in subsection 4.2 .

\subsection{Updating of Beliefs}

Before proceeding with the analysis, it is useful to first look at the raw data. In particular, looking only at the periods in which subjects acquired the pricing information $\left(F_{t}, p_{t}\right)$, whatever the quantity decision $x_{t}$ in that period was, a subject should expect to pay $F_{t}+p_{t} x_{t}$ if using all available information and doing the computations correctly. Looking at the data, the average value of $C_{t}^{e}-C_{t}$ is such periods is -0.23 , which is statistically indistinguishable from 0 . However, this average hides a fairly large standard deviation of 10.4. Hence, although subjects do not systematically under- or over-estimate the amount they are going to pay for their purchases, they nevertheless make case-by-case errors that are sometimes sizeable. What is the significance of this finding for our data analysis? Due to small computational mistakes, the actual expected payment reported by a subject may be different from $F_{t}+p_{t} x_{t}$ even if the subject knows $\left(F_{t}, p_{t}\right)$, understands the experiment 
and tries to provide his or her best estimate. On the other hand, if the discrepancy is "large," this may be indicative of a subject who either tried to provide his or her best estimate but was confused about the experiment, or of a subject who, due to the fact that this belief elicitation was not incentivized, simply provided a random estimate. Because such confusion or negligence is likely to extend to periods in which the subject does not acquire the pricing information, either of the two cases poses a problem for computing the mean belief about the per-unit price according to equation (4) in those periods. For this reason, apart from analyzing the entire sample, we will also split it into two different groups, labeled G1a and G1b, which will be analyzed separately. G1a will consist of subjects whose expectation of $F_{t}+p_{t} x_{t}$ when $\left(F_{t}, p_{t}\right)$ is known does not differ from its actual value by more than some threshold value on average. G1b will consist of the remaining subjects. Inspecting the distribution of average per-subject discrepancies between the expectation of $F_{t}+p_{t} x_{t}$ and its actual value in periods when $\left(F_{t}, p_{t}\right)$ is known, out of 107 subjects, this value is equal to 0 for 20 subjects, does not exceed 1 for 55 subjects, 2 for 71 subjects, 3 for 76 subjects, 4 for 79 subjects, 5 for 85 subjects and 6 for 92 subjects. Based on this distribution, we take 2 to be the relevant threshold for defining G1a and G1b.

Likewise, looking only at periods in which subjects did acquire the pricing information $\left(F_{t}, p_{t}\right)$, equation (7) implies that if subjects maximize their payoff, they should choose $x_{t}=11-p_{t}$ if using all available information and doing the computations correctly. As in the previous case, even if a subject understands the experiment, small computational mistakes or initial learning about what optimal quantity to demand may result in small average per-subject discrepancies between $x_{t}$ and $11-p_{t}$. On the other hand, "large" average discrepancies may indicate confusion about the experiment or optimal purchasing behavior. Again, because such confusion or negligence is likely to extend to periods in which the subject does not acquire the pricing information, this poses a problem for computing the mean belief about the per-unit price according to equation (8) in those periods. So like in the previous case, apart from analyzing the entire sample, we will also split it into two different groups, labeled G2a and G2b, which will be analyzed separately. G1a will consist of subjects whose choice of $x_{t}$ when $\left(F_{t}, p_{t}\right)$ is known does not differ from $11-p_{t}$ 
by more than some threshold value on average. G2b will consist of the remaining subjects. Inspecting the distribution of average per-subject discrepancies between $x_{t}$ and $11-p_{t}$ in periods when $\left(F_{t}, p_{t}\right)$ is known, out of 107 subjects, this value is equal to 0 for 41 subjects, does not exceed 0.25 for 61 subjects, 0.5 for 71 subjects, 0.75 for 76 subjects, 1 for 80 subjects, 1.5 for 90 subjects and 2 for 100 subjects. Based on this distribution, we take 0.5 to be the relevant threshold for defining G2a and G2b.

Table 3 shows the joint distribution of subjects across the two groups. Slightly less than half of all subjects (56) are in both G1a and G2a, whereas 21 subjects are in both G1b and G2b. Note that there is one subject who never acquired any information and this subject is classified as belonging to both G1b and G2b.

Panel A of Figure 1 presents a scatterplot of $p_{i j t}^{e}$ against $u^{T} \omega_{i j t}^{E A}$, where $i$ indexes subjects, $j$ indexes stages and $t$ indexes periods (as before). A casual observation suggests that the 45-degree line that captures Hypothesis 1 does account for a significant proportion of variation in the data. To test this more formally, column (1) of Table 4 presents coefficient estimates from a regression of $p_{i j t}^{e}$ on the constant and $u^{T} \omega_{i j t}^{E A}$. In cases of an intercept, asterisks denote a statistically significant difference from 0 , whereas in cases of a slope, they denote a statistically significant difference from 1 . The table also presents a p-value of the joint $F$ test of the two hypotheses. All standard errors and test statistics are adjusted for clustering at the subject level. Although the slope, estimated at 0.944, is insignificantly different from 1 , the intercept is positive and statistically significant at the 5 -percent level. The p-value of the $F$ test reveals that the joint hypothesis is barely rejected at the 10percent level. Panels A1a and A1b of Figure 1 and columns (2) and (3) in Table 4 repeat the exercise only for subjects in groups G1a and G1b, respectively. In group G1a, the intercept is statistically indistinguishable from 0 , whereas the slope is significantly different from 1 only at the 10-percent level. In group G1b, the intercept is significantly above zero and the slope is significantly above 1. Overall, the Bayesian model provides a reasonable fit for data from subjects in group G1a, but not for subjects from group G1b. This is also reflected by $R^{2}$ being 0.61 in column (2) and only 0.20 in column (3). This leads to our first result. 
Result 1 We cannot reject the hypothesis $E\left(p_{t}^{e} \mid u^{T} \omega_{t}^{E A}\right)=u^{T} \omega_{t}^{E A}$ for subjects who provide relatively precise estimates of their total cost of purchase in periods when $\left(F_{t}, p_{t}\right)$ is known (group G1a), but we can reject it for the other subjects (group G1b).

Panel B of Figure 1 presents a scatterplot of $p_{i j t}^{e e}$ against $u^{T} \omega_{i j t}^{E A}$. Again, a casual inspection suggests that the 45-degree line that captures Hypothesis 2 does account for a significant portion of variation in the data. Column (4) of Table 4 presents coefficient estimates from a regression of $p_{i j t}^{e e}$ on the constant and $u^{T} \omega_{i j t}^{E A}$. The intercept is positive and statistically significantly different from 0 at the 10-percent level, whereas the slope is slightly less that 1 and statistically significantly different from 1 at the 10-percent level as well. However, the joint test statistic is insignificant. Panels B2a and B2b of Figure 1 and columns (5) and (6) in Table 4 repeat the exercise only for subjects in groups G2a and G2b, respectively. In group G2a, the intercept is statistically indistinguishable from 0 and the slope is statistically indistinguishable from 1. In group G2b, the intercept is significantly above zero and the slope is significantly below 1 . Overall, the results for $p_{t}^{e e}$ are very similar to the results for $p_{t}^{e}$. The Bayesian model provides a reasonable fit for data from subjects in group G2a, but not for subjects in group G2b. This is also reflected by $R^{2}$ being 0.91 in column (5) and only 0.52 in column (6). We therefore conclude the following:

Result 2 We cannot reject the hypothesis $E\left(p_{t}^{e e} \mid u^{T} \omega_{t}^{E A}\right)=u^{T} \omega_{t}^{E A}$ for subjects whose purchase quantities deviate relatively little from $11-p_{t}$ in periods when $\left(F_{t}, p_{t}\right)$ is known (group G2a), but we can reject it for the other subjects (group G2b).

\subsection{Information Demand}

Table 5 presents estimates of various linear probability models of information demand that account for subject fixed effects. All four specifications control for the cost of information (S2,S4,S6,S8,SR with SA being the omitted category) and period $t$ within each stage. Furthermore, specifications (3) and (4) also non-parametrically control for the discrepancy $C_{t-1}-C_{t-1}^{e}$ between realized and expected cost of purchase in the previous period. This discrepancy is defined to be zero in periods in which the pricing information is known and 
zero is the omitted category in the list of the non-parametric controls. Finally, specifications (2) and (4) also control for $\omega_{t-1}^{E P}$ (coefficient estimates not displayed). All standard errors are adjusted for clustering at the subject level.

All four specifications reveal that the demand for information is quite sensitive to its cost and that the estimated coefficients on various cost categories are very consistent across the four specifications. In particular, ceteris paribus, a subject is more likely to acquire the pricing information by about 43 percentage points when its cost is 2 compared to when it is 8, and the difference is statistically highly significant. We therefore conclude the following:

Result 3 The demand for pricing information is, ceteris paribus, decreasing in its cost. We therefore cannot reject Hypothesis 3.

On the other hand, the period within a stage has a negative impact on the demand for information only in specification (1). Once $\omega_{t-1}^{E P}$ is controlled for in specification (2), the negative impact disappears completely. The coefficient on the period within a stage is also not statistically significant in specifications (3) and (4). This leads to the following conclusion:

Result 4 Controlling for the cost of information and $\omega_{t-1}^{E P}$, the demand for pricing information is insensitive to the number of the remaining periods. We therefore reject Hypothesis 4.

Next, turning to specification (3), we observe that controlling for the cost of information and period, the sign of surprise in the cost of purchase in the previous period has a very asymmetric effect on the demand for information. In particular, lower-than-expected cost realizations reduce, and large higher-than-expected cost realizations increase, the demand for information compared to the baseline of no surprise. Note that the coefficient estimates on the individual cost surprise categories are almost identical in specification (4) despite the fact that we control for the posterior belief $\omega_{t-1}^{E P}$ that should already account for any belief-relevant information conveyed by $C_{t-1}-C_{t-1}^{e}$. We therefore conclude the following: 
Result 5 Controlling for the cost of information and t, the demand for pricing information increases with realizations of $C_{t-1}-C_{t-1}^{e}$. We therefore reject Hypothesis 5.

\section{Conclusion}

This paper conducts a laboratory study of consumer behavior in repeated purchase tasks in which the total cost of purchase is determined by a two-part tariff pricing scheme. The fixed fee is independent across periods, whereas the per-unit price is serially correlated. The fixed fee and the per-unit price are not known in any of the periods, but subjects have an opportunity to learn them at a cost. In the opposite case, they have to rely on updating of their beliefs based on the total cost of purchase that is displayed to them at the end of each period. The paper finds that (1) conditional on information acquisition decisions, the model of Bayesian updating provides a good approximation for revealed mean beliefs about the per-unit price held by subjects who appear to understand the experiment and/or report their expected cost of purchase accurately; it is not a good approximation for other subjects; (2) the demand for information decreases in the cost of information, as expected; (3) controlling for Bayesian beliefs and cost of information, the demand for information does not vary with the length of the remaining time horizon in which the information can be used, contrary to the theoretical prediction; (4) large positive surprises in the cost of purchase in the most recent period increase information demand, whereas negative surprises decrease it, relative to the no-surprise baseline, which is contrary to the theoretical prediction.

These findings suggest that a standard model of the demand for information based on Bayesian updating, value of information and backward induction does not provide a good approximation to the actual behavior of consumers. Particularly, consumers may be much more active in acquiring pricing information if their recent purchase bill ended up being higher than expected than in the case it ended up being lower than expected. This happens despite the fact that getting the pricing information may be equally valuable for adjusting one's future consumption in either of the two cases. This finding poses a puzzle and more 
future work is necessary to resolve it. 


\section{References}

de Bartolome, C. A. M., "Which Tax Rate Do People Use - Average or Marginal," Journal of Public Economics, 1995, 56 (1), 79-96.

Feldman, Naomi and Peter Katuščák, "The Effect of Predictable Tax Liability Variation on Household Labor Income," CERGE-EI Discussion Paper No. 210 December 2010.

Fischbacher, Urs, "z-Tree: Zurich Toolbox for Ready-made Economic Experiments," Experimental Economics, 2007, 10 (2), 171-178.

Gaudin, Sylvestre, "Effect of Price Information on Residential Water Demand," Applied Economics, 2006, 38 (4), 383-393.

Liebman, Jeffrey B. and Richard J. Zeckhauser, "Schmeduling," Manuscript, Harvard, October 2004. 


\section{Appendix A: Tables and Figures}

\section{Table 1: Induced Demand}

\begin{tabular}{ccc}
\hline \hline Unit & Marginal value & Total value \\
\hline 1 & 30.5 & 30.5 \\
2 & 9.5 & 40.0 \\
3 & 8.5 & 48.5 \\
4 & 7.5 & 56.0 \\
5 & 6.5 & 62.5 \\
6 & 5.5 & 68.0 \\
7 & 4.5 & 72.5 \\
8 & 3.5 & 76.0 \\
9 & 2.5 & 78.5 \\
10 & 1.5 & 80.0 \\
\hline \hline
\end{tabular}

Note: All valuations are expressed in experimental currency units (ECUs).

Table 2: Transition Matrix for the Per-unit Price

\begin{tabular}{|c|c|c|c|c|c|c|c|c|c|c|}
\hline$p_{t}^{p_{t-1}}$ & 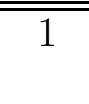 & 2 & 3 & 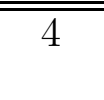 & 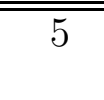 & 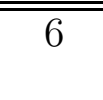 & 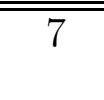 & 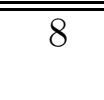 & 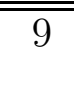 & $\overline{10}$ \\
\hline 1 & $1 / 2$ & $1 / 6$ & $1 / 12$ & & & & & & & \\
\hline 2 & $1 / 3$ & $1 / 2$ & $1 / 6$ & $1 / 12$ & & & & & & \\
\hline 3 & $1 / 6$ & $1 / 6$ & $1 / 2$ & $1 / 6$ & $1 / 12$ & & & & & \\
\hline 4 & & $1 / 6$ & $1 / 6$ & $1 / 2$ & $1 / 6$ & $1 / 12$ & & & & \\
\hline 5 & & & $1 / 12$ & $1 / 6$ & $1 / 2$ & $1 / 6$ & $1 / 12$ & & & \\
\hline 6 & & & & $1 / 12$ & $1 / 6$ & $1 / 2$ & $1 / 6$ & $1 / 12$ & & \\
\hline 7 & & & & & $1 / 12$ & $1 / 6$ & $1 / 2$ & $1 / 6$ & $1 / 6$ & \\
\hline 8 & & & & & & $1 / 12$ & $1 / 6$ & $1 / 2$ & $1 / 6$ & $1 / 6$ \\
\hline 9 & & & & & & & $1 / 12$ & $1 / 6$ & $1 / 2$ & $1 / 3$ \\
\hline 10 & & & & & & & & $1 / 12$ & $1 / 6$ & $1 / 2$ \\
\hline
\end{tabular}

Note: The table lists conditional probabilities $P\left(p_{t} \mid p_{t-1}\right)$. The left-out entries are zeros. 
Table 3: Distribution of Subjects across Groups

\begin{tabular}{cccc}
\hline \hline & G2a & G2b & Sum \\
\hline G1a & 56 & 15 & 71 \\
G1b & 15 & 21 & 36 \\
\hline Sum & 71 & 36 & 107 \\
\hline \hline
\end{tabular}

Table 4: Slope and Intercept Estimates from OLS Regressions of $p_{t}^{e}$ and $p_{t}^{e e}$ on $u^{T} \omega_{t}^{E A}$

\begin{tabular}{lllllll}
\hline \hline & $(1)$ & $(2)$ & $(3)$ & $(4)$ & $(5)$ & $(6)$ \\
Subjects & All & G1a & G1b & All & G2a & G2b \\
\hline Intercept & $0.356^{* *}$ & -0.072 & $0.762^{* * *}$ & $0.235^{*}$ & -0.043 & $0.827^{* *}$ \\
Slope & 0.944 & $1.039^{*}$ & $1.216^{* *}$ & $0.967^{*}$ & 1.013 & $0.869^{* *}$ \\
\hline Joint F-test p-value & 0.096 & 0.088 & 0.044 & 0.17 & 0.30 & 0.049 \\
$R^{2}$ & 0.41 & 0.61 & 0.20 & 0.76 & 0.91 & 0.52 \\
\hline \hline
\end{tabular}

Notes:

1. The asterisks denote statistically significant differences from 0 in cases of the intercepts and 1 in cases of the slopes.

2. Statistically significant at $* 10 \%, * * 5 \%, * * * 1 \%$. 
Table 5: Estimates of Linear Probability Models for Demanding Pricing Information with Subject Fixed Effects

\begin{tabular}{|c|c|c|c|c|}
\hline & 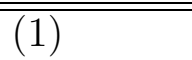 & 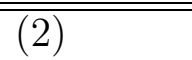 & 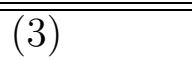 & 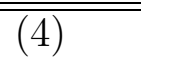 \\
\hline$c=2$ & $\begin{array}{l}0.288^{* * *} \\
(0.000)\end{array}$ & $\begin{array}{l}0.306^{* * *} \\
(0.000)\end{array}$ & $\begin{array}{l}0.295^{* * *} \\
(0.000)\end{array}$ & $\begin{array}{l}0.295^{* * *} \\
(0.000)\end{array}$ \\
\hline$c=4$ & $\begin{array}{l}0.072^{* * *} \\
(0.004)\end{array}$ & $\begin{array}{l}0.074^{* * *} \\
(0.005)\end{array}$ & $\begin{array}{l}0.073^{* * *} \\
(0.005)\end{array}$ & $\begin{array}{l}0.071^{* * *} \\
(0.007)\end{array}$ \\
\hline$c=6$ & $\begin{array}{l}-0.067^{* * *} \\
(0.004)\end{array}$ & $\begin{array}{l}-0.064^{* * *} \\
(0.009)\end{array}$ & $\begin{array}{l}-0.063^{* * *} \\
(0.007)\end{array}$ & $\begin{array}{l}-0.062^{* * *} \\
(0.007)\end{array}$ \\
\hline$c=8$ & $\begin{array}{l}-0.146^{* * *} \\
(0.000)\end{array}$ & $\begin{array}{l}-0.141^{* * *} \\
(0.000)\end{array}$ & $\begin{array}{l}-0.136^{* * *} \\
(0.000)\end{array}$ & $\begin{array}{l}-0.137^{* * *} \\
(0.000)\end{array}$ \\
\hline$c$ risky & $\begin{array}{l}0.023 \\
(0.265)\end{array}$ & $\begin{array}{l}0.026 \\
(0.221)\end{array}$ & $\begin{array}{l}0.027 \\
(0.197)\end{array}$ & $\begin{array}{l}0.026 \\
(0.208)\end{array}$ \\
\hline$t$ & $\begin{array}{l}-0.021^{* * *} \\
(0.000)\end{array}$ & $\begin{array}{l}-0.000 \\
(0.808)\end{array}$ & $\begin{array}{l}0.001 \\
(0.412)\end{array}$ & $\begin{array}{l}0.001 \\
(0.647)\end{array}$ \\
\hline$\left(C_{t-1}^{e}-C_{t-1}\right) \leq-11$ & & & $\begin{array}{l}-0.067^{* *} \\
(0.040)\end{array}$ & $\begin{array}{c}-0.068^{*} \\
(0.058)\end{array}$ \\
\hline$-10 \leq\left(C_{t-1}^{e}-C_{t-1}\right) \leq-$ & & & $\begin{array}{l}-0.046 \\
(0.112)\end{array}$ & $\begin{array}{l}-0.046 \\
(0.114)\end{array}$ \\
\hline$-5 \leq\left(C_{t-1}^{e}-C_{t-1}\right) \leq-1$ & & & $\begin{array}{l}-0.092^{* * *} \\
(0.005)\end{array}$ & $\begin{array}{l}-0.092^{* * *} \\
(0.005)\end{array}$ \\
\hline $1 \leq\left(C_{t-1}^{e}-C_{t-1}\right) \leq 5$ & & & $\begin{array}{l}-0.049 \\
(0.140)\end{array}$ & $\begin{array}{l}-0.049 \\
(0.137)\end{array}$ \\
\hline $6 \leq\left(C_{t-1}^{e}-C_{t-1}\right) \leq 10$ & & & $\begin{array}{l}0.016 \\
(0.639)\end{array}$ & $\begin{array}{l}0.017 \\
(0.594)\end{array}$ \\
\hline $11 \leq\left(C_{t-1}^{e}-C_{t-1}\right)$ & & & $\begin{array}{l}0.073^{* *} \\
(0.026)\end{array}$ & $\begin{array}{l}0.072^{* *} \\
(0.023)\end{array}$ \\
\hline constant & $\begin{array}{l}0.450 * * * \\
(0.000)\end{array}$ & $\begin{array}{l}0.225^{* * *} \\
(0.000)\end{array}$ & $\begin{array}{l}0.276^{* * *} \\
(0.000)\end{array}$ & $\begin{array}{l}0.219^{* * *} \\
(0.000)\end{array}$ \\
\hline & no & yes & no & yes \\
\hline Observations & 7,704 & 7,062 & 7,062 & 7,062 \\
\hline Subjects & 107 & 107 & 107 & 107 \\
\hline$R^{2}$ & 0.12 & 0.12 & 0.13 & 0.13 \\
\hline
\end{tabular}

Notes:

1. Standard errors are adjusted for clustering at the subject level.

2. Statistically significant at $* 10 \%, * * 5 \%, * * * 1 \%$. 
Figure 1: Scatterplots of $p_{t}^{e}$ and $p_{t}^{e e}$ against $u^{T} \omega_{t}^{E A}$
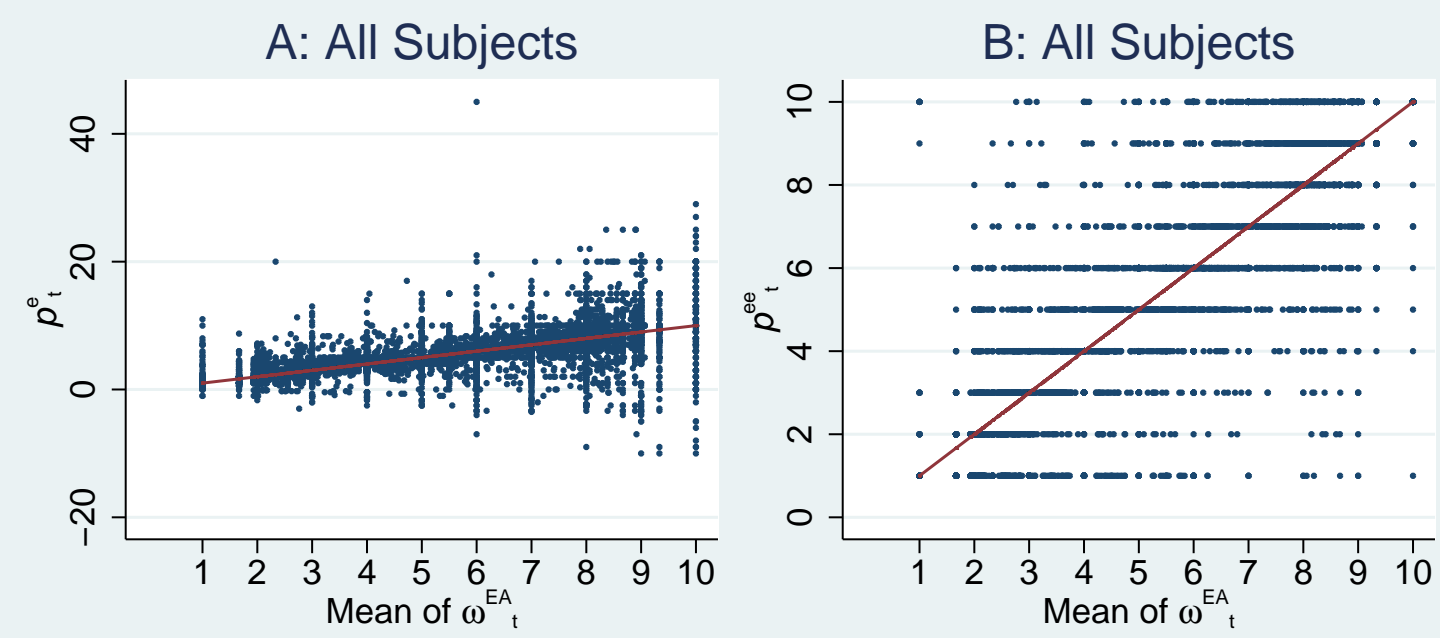

A1a: Subjects from G1a
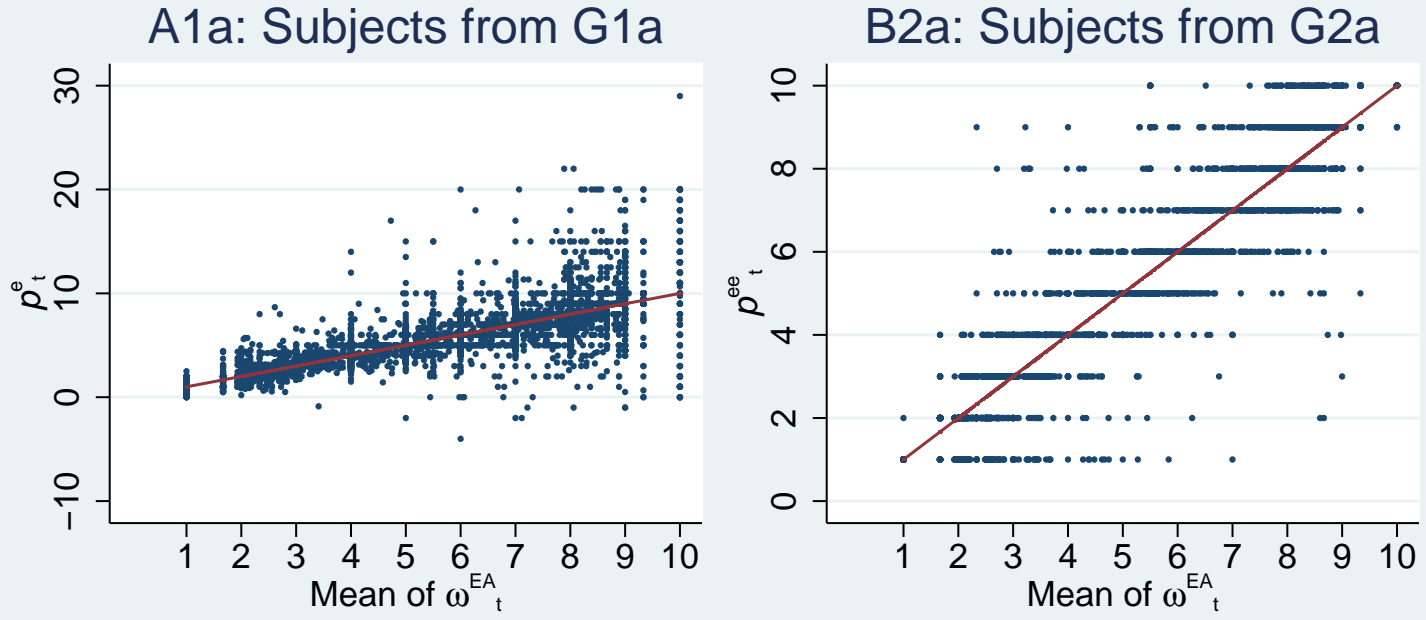

A1b: Subjects from G1b

B2b: Subjects from G2b
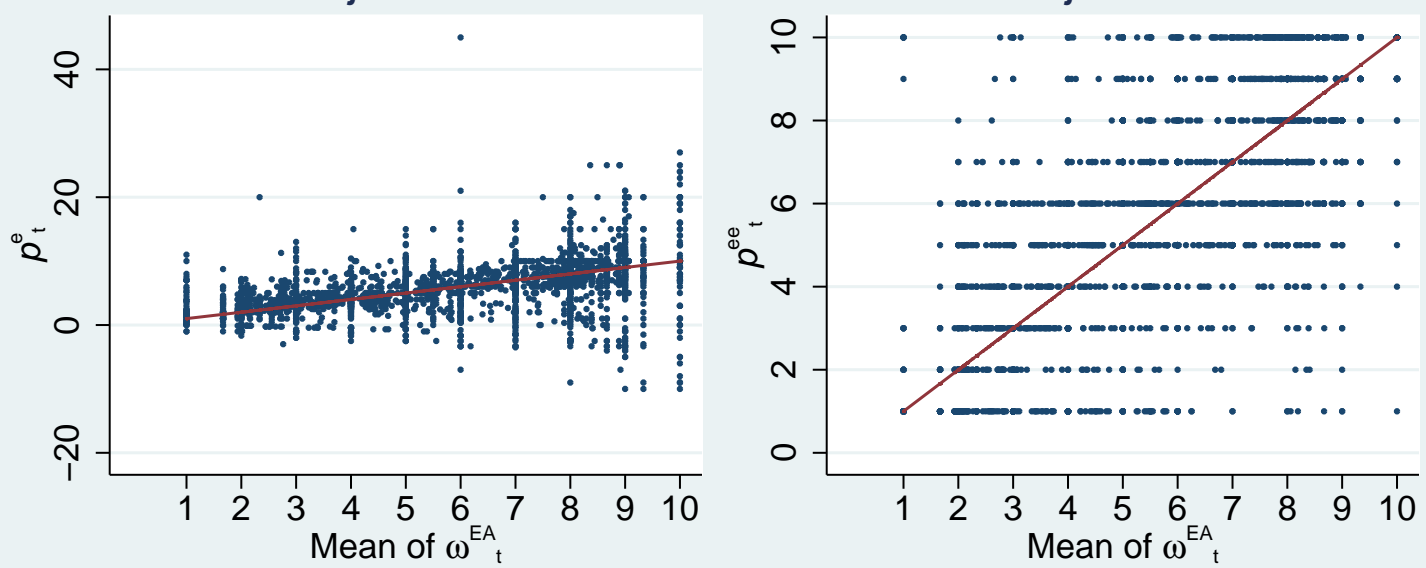

Notes: The 45-degree line is displayed in each panel. 


\section{Appendix B: Proofs}

Proof of Proposition 1:. The first part of the Proposition is immediate. If $a_{t}=0$ and $t=1$, then $\omega_{t}^{E A}=(1 / 10) r$ follows directly from the design of the distribution of the per-unit price in the first period of each stage. If $a_{t}=0$ and $t \geq 2$, then

$$
\omega_{t}^{E A}=A \omega_{t-1}^{E P}
$$

follows directly from the design of the price transition process. If $a_{t}=0, \omega_{t}^{E P}$ is derived from $\omega_{t}^{E A}$ based on the observation of $C_{t}$ using Bayesian updating. To begin with, note that

$$
\begin{aligned}
P_{\omega_{t}^{E A}}\left(C_{t} \mid x_{t}, p_{t}\right) & =\left\{\begin{array}{cl}
\frac{1}{21} & \text { if } p_{t} x_{t} \leq C_{t} \leq p_{t} x_{t}+20 \\
0 & \text { otherwise }
\end{array}\right. \\
& =\left\{\begin{array}{cl}
\frac{1}{21} & \text { if } \frac{C_{t}-20}{x_{t}} \leq p_{t} \leq \frac{C_{t}}{x_{t}} \\
0 & \text { otherwise }
\end{array}\right.
\end{aligned}
$$

and hence

$$
P_{\omega_{t}^{E A}}\left(C_{t} \mid x_{t}\right)=\frac{1}{21} P_{\omega_{t}^{E A}}\left\{\frac{C_{t}-20}{x_{t}} \leq p_{t} \leq \frac{C_{t}}{x_{t}}\right\} .
$$

Now note that since $x_{t}$ is fully controlled by the subject,

$$
P_{\omega_{t}^{E A}}\left(p_{t} \mid x_{t}\right)=P_{\omega_{t}^{E A}}\left(p_{t}\right)
$$

In these equations, the notation $P_{\omega_{t}^{E A}}(\cdot)$ refers to the probability being evaluated using the belief $\omega_{t}^{E A}$. Then, substituting from $(\mathrm{A}-2)-(\mathrm{A}-4), \omega_{t}^{E P}$ can be derived from $\omega_{t}^{E A}$ by

$$
\begin{aligned}
P_{\omega_{t}^{E P}}\left(p_{t} \mid C_{t}, x_{t}\right) & =\frac{P_{\omega_{t}^{E A}}\left(C_{t} \mid x_{t}, p_{t}\right) P_{\omega_{t}^{E A}}\left(p_{t} \mid x_{t}\right)}{P_{\omega_{t}^{E A}}\left(C_{t} \mid x_{t}\right)} \\
& =\left\{\begin{array}{cl}
\frac{P_{\omega_{t}^{E A}}\left(p_{t} \mid x_{t}\right)}{P_{\omega_{t}^{E A}\left\{\frac{C_{t}-20}{x_{t}} \leq p_{t} \leq \frac{C_{t}}{x_{t}}\right\}}} & \text { if } \frac{C_{t}-20}{x_{t}} \leq p_{t} \leq \frac{C_{t}}{x_{t}} \\
0 & \text { otherwise }
\end{array}\right.
\end{aligned}
$$


This can be succintly expressed as

$$
\omega_{t-1}^{E P}=\frac{\operatorname{diag}\left[v\left(C_{t}, x_{t}\right)\right] \omega_{t-1}^{E A}}{v\left(C_{t}, x_{t}\right) \omega_{t-1}^{E A}} .
$$




\section{Appendix C: Experimental Instructions}

\section{Introduction}

- You are about to participate in a decision process in which you will be repeatedly buying a certain quantity of an (imaginary) good that you will in turn resell to the experimenter. This experiment is a part of a study intended to provide insight into certain features of consumers' decision-making processes.

- Throughout the experiment, all prices and payment amounts are stated in points. Your total point earnings in the experiment will be converted to Czech crowns, and you will be paid in cash at the end of the experiment. If you follow the instructions carefully and make good decisions, you may earn a considerable amount of money.

- This is an experiment in individual decision making, without any strategic interaction with other subjects. Your earnings will depend solely on your decisions. Your earnings will in no way depend on decisions made by other subjects.

- During the experiment, please do not talk to each other. If you have a question, please raise your hand and an experimenter will assist you.

\section{Procedure}

- You each have drawn an instruction form with a number on it. This is the number of your computer terminal. Please be seated at that terminal.

- The experiment consists of one practice stage without payoffs, six stages with payoffs and a questionnaire. The practice stage consists of 5 periods in which you will repeat the purchase process. This stage will get you accustomed to the purchase task. Each payoff stage consists of 12 periods in which you will repeat the purchase process.

- In each period, you will be deciding on the number of units of the good to buy, where the amount can be any integer between 1 and 10 . 
- The total amount you pay for your purchase in a given period is determined by:

1. A fixed fee drawn randomly by the computer in every period from values $0,1,2$, $\ldots, 20$, each of them with an equal probability of $1 / 21$. This fee is determined independently in every period and fees in different periods are not related. You will be charged this fixed fee no matter how many units of the good you purchase.

2. A per-unit price for each unit of the good you purchase. The per-unit price in every period is one of the values $1,2, \ldots, 10$. In the first period of every stage, the computer draws the per-unit price randomly from values $1,2, . ., 10$, each of them with an equal probability of $1 / 10$. In every subsequent period of that stage, the per-unit price for that period is determined as follows:

(a) With probability $1 / 2(50 \%)$, the per-unit price is equal to the per-unit price in the previous period.

(b) With probability $1 / 3$ (approximately 33.3\%), the per-unit price changes by 1 compared to the per-unit price in the previous period. In this case, the per-unit price is equally likely to increase or decrease by 1 , unless the price in the previous period is 1 , in which case only an increase is possible, or 10 , in which case only a decrease is possible.

(c) With probability 1/6 (approximately 16.7\%), the per-unit price changes by 2 compared to the per-unit price in the previous period. In this case, the per-unit price is equally likely to increase or decrease by 2 , unless the price in the previous period is 1 or 2 , in which case only an increase is possible, or 9 or 10, in which case only a decrease is possible.

- Your total payment for a purchase of $x$ units of the good is then given by $F+p x$, where $F$ is the fixed fee and $p$ is the per-unit price. For example, suppose that you buy 3 units when the fixed fee is 12 and the per-unit price is 6 . The total amount you pay for your purchase is $12+6 \times 3=30$.

- You will not automatically be informed about the fixed fee and the per-unit price 
in any given period. However, before making your purchase decision in any period, you will have an option to acquire information about the exact fixed fee and per-unit price in that period at a certain cost. This cost may be 2,4,6 or 8 , and in some stages it may change from period to period. You may or may not be given additional details about the cost of information before you decide whether to acquire the information.

- At the end of each period, you automatically resell the units of the good you purchased to the experimenter. The amount paid to you by the experimenter, or the resale value, is determined by the following table:

\begin{tabular}{lcc}
\hline \hline $\begin{array}{l}\text { Order number } \\
\text { of the unit }\end{array}$ & $\begin{array}{c}\text { Resale value } \\
\text { of the unit }\end{array}$ & $\begin{array}{c}\text { Resale value of this } \\
\text { and all the previous units }\end{array}$ \\
\hline 1st unit & 30.5 & 30.5 \\
2nd unit & 9.5 & 40 \\
3rd unit & 8.5 & 48.5 \\
4th unit & 7.5 & 56 \\
5th unit & 6.5 & 62.5 \\
6th unit & 5.5 & 68 \\
7th unit & 4.5 & 72.5 \\
8th unit & 3.5 & 76 \\
9th unit & 2.5 & 88.5 \\
10th unit & 1.5 & 80 \\
\hline \hline
\end{tabular}

For example, if you purchase 5 units, the resale value is 62.5 , which is higher by 6.5 compared to the resale value of 4 units, and lower by 5.5 compared to the resale value of 6 units.

- Each stage begins simultaneously for all subjects. Please be patient and wait at the end of each stage if you progress through it faster than other subjects.

\section{Your Earnings}


- Your earnings in a given period are determined as follows:

\section{Your earnings $=$ Resale value for all the units you have purchased - Total amount you pay to purchase that number of units - Cost of information if information is acquired}

- For example, suppose that you buy 7 units when the fixed fee is 8 and the per-unit price is 6 . The total amount you pay for your purchase is $8+6 \times 7=50$. You sell those 7 units back to the experimenter for 72.5. As a result, if you do not acquire information about the fixed fee and the per-unit price in that period, your earnings for the period would be $72.5-50=22.5$. If you do acquire the information, your earnings would be reduced by the cost of information in that period.

- Your cash earnings for the experiment will consist of a show-up fee of $100 \mathrm{Kč} \mathrm{and} \mathrm{a}$ variable part that will depend on how well you do in the experiment. In particular, we will compute your average period point earnings across all 72 periods in stages 1 through 6 , and you will be paid an additional 20 Kč for each point by which this average exceeds 15 points. In case this average falls short of 15 points, you will be paid the show-up fee of 100 Kč.

\section{Questionnaire}

- After finishing all the stages of the experiment, please remain seated at your terminal and fill out a short questionnaire about your background, your recent purchase behavior and a few other hypothetical questions.

\section{Review Questions}

The following review questions are designed to help you in understanding the experimental design. Please answer each of them, and afterwards we will go through them together. 
1. Is the fixed fee the same in every period of a given stage?

2. Does the fixed fee in a given period depend on what that fee was in the previous period?

3. Does the per-unit price in a given period depend on what that per-unit price was in the previous period?

4. Suppose the per-unit price was 7 in the previous period. What do you expect the per-unit price to be this period on average? With what probability will it actually be equal to that?

5. Suppose the per-unit price was 1 in the previous period. Do you expect the per-unit price to be higher on average this period?

6. Suppose the per-unit price was 10 in the previous period. Do you expect the per-unit price to be lower on average this period?

7. Can your point earnings be negative in a particular period?

8. Can you avoid negative point earnings in a given period? If yes, how? 


\section{Appendix D: Questionnaire}

Please answer the following questions. Your answers will be kept strictly confidential and will be used for research purposes only.

1. Your gender:

2. Your age:

3. Your country of origin:

4. Your number of siblings:

5. Your academic major/field of study:

6. Your highest earned degree so far ("none" may be an answer)

7. Do you use a cell/mobile phone for whose usage you pay? Yes/no

If your answer to question 7 is yes:

7.a What company is your mobile phone service provider?

7.b What plan or a pre-paid service of this company are you signed up for?

7.c If your plan comes with a fixed number of minutes included in the monthly fee, would you say that you exceed this limit: never/infrequently/regularly/(almost) always

7.d Do you pay attention to how much each additional minute of calling costs you ( in case of a plan with a fixed number of included minutes, each minute over this limit ) $?$ yes $/$ no

7.e Please, give an estimate of this per minute cost for a minute during:

7.e.a day hours during weekdays?

7.e.b evening hours during weekdays?

7.e.c weekends and holidays? 
8.a Have you, during 2009 or 2008 had any income from an Agreement on Execution of Labor ("Dohoda o provedení práce")? yes/no

8.b Suppose you were working under such Agreement on Execution of Labor. How much of each additional $1000 \mathrm{Kc}$ of pre-tax (gross) wage from such contract would you have to pay in income taxes?

9.a Have you had a regular job during 2008 or 2009 in the Czech Republic with your employer contributing toward your health and social security insurance? yes/no

9.b Suppose you were working under such employee contract. How much of each additional $1000 \mathrm{Kc}$ of pre-tax (gross) wage from such contract would you have to pay in income taxes?

10. Suppose you have a bank account in the Czech Republic that pays you interest. Suppose the bank pays you $1000 \mathrm{Kc}$ of interest. How much income tax would be deducted from this interest earning?

11. What is (are) the Value Added Tax (DPH) rate(s) in the Czech Republic? (you may list multiple rates)

12. Please describe how you were deciding on:

12.a whether to buy information?

12.b how many units to buy if you knew the fixed fee and the per-unit price?

12.c how to update your beliefs about the per-unit price from the observation of the actual payment for the purchase? 


\section{Working Paper Series}

ISSN 1211-3298

Registration No. (Ministry of Culture): E 19443

Individual researchers, as well as the on-line and printed versions of the CERGE-EI Working Papers (including their dissemination) were supported from the following institutional grants:

- Economic Aspects of EU and EMU Entry [Ekonomické aspekty vstupu do Evropské unie a Evropské měnové unie], No. AVOZ70850503, (2005-2011);

- Economic Impact of European Integration on the Czech Republic [Ekonomické dopady evropské integrace na ČR], No. MSM0021620846, (2005-2011);

Specific research support and/or other grants the researchers/publications benefited from are acknowledged at the beginning of the Paper.

(c) Peter Katuščák, 2011

All rights reserved. No part of this publication may be reproduced, stored in a retrieval system or transmitted in any form or by any means, electronic, mechanical or photocopying, recording, or otherwise without the prior permission of the publisher.

Published by

Charles University in Prague, Center for Economic Research and Graduate Education (CERGE) and

Economics Institute ASCR, v. v. i. (EI)

CERGE-EI, Politických vězňů 7, 11121 Prague 1, tel.: +420 224005 153, Czech Republic.

Printed by CERGE-EI, Prague

Subscription: CERGE-EI homepage: http://www.cerge-ei.cz

Phone: + 420224005153

Email: office@cerge-ei.cz

Web: http://www.cerge-ei.cz

Editor: Michal Kejak

Editorial board: Jan Kmenta, Randall Filer, Petr Zemčík

The paper is available online at http://www.cerge-ei.cz/publications/working_papers/.

ISBN 978-80-7343-234-8 (Univerzita Karlova. Centrum pro ekonomický výzkum a doktorské studium)

ISBN 978-80-7344-224-8 (Národohospodářský ústav AV ČR, v. v. i.) 
CERGE-EI

P.O.BOX 882

Politických vězňů 7

11121 Praha 1

Czech Republic http://www.cerge-ei.cz 